\title{
CORNEAL AUTOIMMUNITY IN PATIENTS WITH PERIPHERAL ULCERATIVE KERATITIS (PUK) IN ASSOCIATION WITH RHEUMATOID ARTHRITIS AND WEGENER'S GRANULOMATOSIS
}

\author{
S. L. JOHN ${ }^{1}$, K. MORGAN ${ }^{1}$, A. B. TULLO ${ }^{2}$, P. J. L. HOLT ${ }^{1}$ \\ Manchester
}

\begin{abstract}
SUMMARY
Serum antibodies to the cornea were investigated in patients with peripheral ulcerative keratitis (PUK) in isolation or in association with a systemic disease (rheumatoid arthritis or Wegener's granulomatosis). Indirect immunofluorescence on bovine corneal sections demonstrated that antibodies bound to epithelial antigens in two distinct patterns: a lattice-like pattern, probably staining intercellular membrane antigens, and a diffuse pattern covering the entire surface of the epithelium. Both patterns were associated with PUK rather than systemic disease whilst the presence of the lattice pattern was more associated with the onset of the PUK. Immunoblotting of sera to corneal epithelial protein extracts demonstrated that a number of corneal antigens were targeted by antibodies. Two antigens, $54 \mathrm{kDa}$ and $70 \mathrm{kDa}$, were of particular interest. Antibodies to the $54 \mathrm{kDa}$ antigen, the major corneal-specific antigen, were also detected by enzyme-linked immunosorbent assay (ELISA). Longitudinal studies showed that these antibodies often first occurred after an episode of PUK. Antibodies to the $70 \mathrm{kDa}$ antigen were related to the Wegener's granulomatosis rather than the PUK.
\end{abstract}

Peripheral ulcerative keratitis (PUK) or corneal melt is a rare but sight-threatening condition which may occur either in isolation or in association with a systemic disease, which is usually an immunologically mediated disorder. $^{1-4}$ The pathogenesis of PUK remains poorly understood but there is evidence for an autoimmune aetiology both in this condition and in other types of peripheral corneal destructive disease. Circulating antibodies to both corneal and conjunctival epithelium have been

From: 'Department of Rheumatology, University of Manchester, ${ }^{2}$ Department of Ophthalmology, Manchester Royal Eye Hospital, UK.

Correspondence to: S. L. John, Department of Rheumatology, University of Manchester, Stopford Building, Oxford Road, Manchester M13 9PT, UK. detected in the serum from patients with peripheral corneal destructive disease. ${ }^{5-8}$ Plasma cell infiltrates, immunoglobulins and complement deposits have been found in the conjunctiva adjacent to the diseased tissue. ${ }^{5,8}$ Cellmediated immunity to corneal antigens has also been reported in patients with corneal disease ${ }^{10,11}$ and in those who have undergone corneal transplantation. ${ }^{12,13}$

Both humoral and cellular immunity to a specific corneal antigen, the $54 \mathrm{kDa}$ protein of the bovine cornea (BSP54), have been demonstrated in patients with peripheral corneal destructive disease. ${ }^{14}$ This protein, which is present in all layers, constitutes approximately $30 \%$ of the soluble proteins of the cornea. ${ }^{15}$ Immunologically similar proteins exist in other species including humans. ${ }^{16}$

In patients with both PUK and systemic disease, antibodies to components of non-corneal tissue may crossreact with corneal antigens and thus contribute to the development of the corneal disease. Alternatively antibodies specific to the cornea may be produced as a result of exposure of corneal-specific antigens to the immune system. It is possible that these antibodies could be involved in the induction of PUK or play a role in disease progression. To investigate these alternatives, we have examined sera from different groups of patients for the presence of antibodies to corneal antigens. The patient groups include patients with PUK in isolation, patients with PUK in association with either Wegener's granulomatosis (WG) or rheumatoid arthritis (RA), and patients with systemic disease but no detectable ocular symptoms.

\section{MATERIALS AND METHODS}

\section{Patients}

Blood was taken from patients attending the Manchester Royal Eye Hospital or the Rheumatology Department of Manchester Royal Infirmary. 
The diagnosis, sex, mean age and age range of the patients are summarised in Table I. The diagnosis of rheumatoid arthritis and Wegener's granulomatosis was made according to the ARA criteria. ${ }^{17,18}$ Blood was collected, allowed to clot at room temperature, and then centrifuged at $1500 \mathrm{~g}$ for 10 minutes. The serum was removed and stored in aliquots at $-20{ }^{\circ} \mathrm{C}$ until required. Sera from normal, healthy blood donors were also included as controls.

\section{Detection of Antibodies to Corneal Antigens by Immunofluorescence}

Sera were tested for antibodies to the cornea by an indirect immunofluorescence technique. Fresh bovine corneas, obtained from the abattoir, were snap frozen in liquid nitrogen. Sections $(5 \mu \mathrm{m})$ were cut in a cryostat, air dried onto 3-(triethoxysilyl)-propylamine-coated glass slides and fixed in acetone for 5 minutes. After washing in phosphate-buffered saline (PBS, pH 7.5) the sections were incubated with patients' or control sera, diluted $1: 20$ in PBS, for 30 minutes at room temperature. After washing, the slides were incubated with fluorescein isothiocyanate (FITC)-conjugated secondary antibody diluted 1:40 in PBS, at room temperature for 30 minutes. The secondary antibodies used were either rabbit anti-human IgGAM, or anti-human IgG, or IgA, or IgM (DAKO Ltd). The slides were washed again in PBS and the sections mounted in glycerol/PBS $(9: 1)$. The slides were examined using a Vickers photoplan microscope at $490 \mathrm{~nm}$ wavelength. Some sera were also tested on rat or human corneal sections which were frozen and prepared in the same way as the bovine cornea. Sera were also tested, by the above technique, using frozen sections of bovine skin, oesophagus or intestine as substrate.

\section{Preparation of Soluble Corneal Epithelial Extract}

Corneal epithelium was removed from fresh bovine eyes. A scalpel blade was used to scrape off the epithelium from the central region of the cornea ensuring no tissue from the limbal region was included. Three hundred milligrams of tissue was homogenised in $5 \mathrm{ml}$ of $0.1 \mathrm{~mol} / \mathrm{l} \mathrm{NaCl}$, $40 \mathrm{mmol} / \mathrm{l} \mathrm{Tris} / \mathrm{HCl} \mathrm{pH} \mathrm{7.8}$. The homogenised extract was then centrifuged at $20000 \mathrm{~g}$ for 30 minutes. The supernatant was dialysed against distilled water for 24 hours, then against $0.01 \mathrm{~mol} / \mathrm{l}$ Tris $\mathrm{HCl} \mathrm{pH} 8$ for 48 hours. The resulting corneal epithelial extract was used as the substrate in the immunoblotting assay. Tissue extracts from bovine liver, kidney and oesophagus were prepared, using the same method, and also used for immunoblotting.

\section{Detection of Antibodies to Corneal Antigen by Immunoblotting}

The proteins in the corneal epithelium extract were separated by SDS-polyacrylamide gel electrophoresis (SDSPAGE) on $10 \%$ acrylamide gels, and transferred to a nitrocellulose membrane by electrophoresis. The nitrocellulose was blocked in 1\% Marvel/PBS/Tween ( $\mathrm{pH} 7.5$ ) for 1 hour at room temperature. Strips of the nitrocellulose were incubated with patients' or control sera diluted $1: 1000$ in Marvel/PBS/Tween (pH 7.5) for 1 hour at room temperature. After washing in PBS/Tween the nitrocellulose was incubated with alkaline phosphatase-conjugated rabbit anti-human IgG (DAKO Ltd), diluted $1: 2000$ in Marvel/PBS/Tween for 1 hour at room temperature. The nitrocellulose strips were then washed in PBS/ Tween and finally in veronal acetate buffer $(0.15 \mathrm{~mol} / \mathrm{l}$ sodium actetate, $0.15 \mathrm{~mol} / \mathrm{l}$ sodium barbitone, $\mathrm{pH}$ 9.6). Following washing, the strips were incubated in $10 \mathrm{ml}$ of substrate $\quad(0.122 \mathrm{mmol} / \mathrm{l}$ nitroblue tetrazolium, $0.115 \mathrm{mmol} / \mathrm{l}$ 5-bromo-4-chloroindoyl phosphate, $4 \mathrm{mmol} / \mathrm{l} \mathrm{MgCl}_{2}$ in veronal acetate buffer, $\mathrm{pH}$ 9.6). The strips were allowed to develop until a brown precipitate indicated where antibody had bound to the protein. The reaction was stopped by washing the nitrocellulose in distilled water to remove the substrate. One patient's serum (NC) was included as a positive standard each time in order to maintain consistency between assays. Protein bands were numbered by reference to equivalent bands on an SDS gel stained for total protein, the lowest molecular weight band being band 1 , approximately $29 \mathrm{kDa}$, and the highest molecular weight band being number 12 , approximately $180 \mathrm{kDa}$.

\section{Purification of the $54 \mathrm{kDa}$ Protein}

In order to purify the $54 \mathrm{kDa}$ protein, the corneal extract in $0.05 \mathrm{~mol} / \mathrm{l} \mathrm{NaCl}, 20 \mathrm{mmol} / \mathrm{l} \mathrm{Tris} / \mathrm{HCl} \mathrm{pH} 7.8$ was loaded onto a $16 \times 1.5 \mathrm{~cm}$ DEAE Sephacel column (Pharmacia Ltd), and eluted in $2 \mathrm{ml}$ fractions. After elution of the first peak, other protein peaks were eluted using $20 \mathrm{mmol} / \mathrm{l}$ Tris/ $\mathrm{HCl}$ (pH 7.8), containing $0.08 \mathrm{~mol} / \mathrm{l} \mathrm{NaCl}, 0.3 \mathrm{~mol} / \mathrm{l}$ $\mathrm{NaCl}$ and $1 \mathrm{~mol} / \mathrm{l} \mathrm{NaCl}$ in succession. The protein eluted by $0.08 \mathrm{~mol} / \mathrm{l} \mathrm{NaCl} 20 \mathrm{mmol} / \mathrm{l} \mathrm{Tris} / \mathrm{HCl}$ (pH 7.8) was predominantly the $54 \mathrm{kDa}$ protein. This solution was dialysed against $20 \mathrm{mmol} / \mathrm{l}$ Tris for 48 hours, and then stored at $-20{ }^{\circ} \mathrm{C}$ in aliquots until required. The $54 \mathrm{kDa}$ protein ran as a single band when $6 \mu \mathrm{g}$ of protein were loaded onto an SDS-polyacrylamide gel. This $54 \mathrm{kDa}$ protein was used in the enzyme-linked immunosorbent assay (ELISA) and the immunoblotting assay.

Table I. Demographic characteristics of patients

\begin{tabular}{lccccc}
\hline & RA & RA + PUK & WG & WG + PUK & Other PUK $^{\text {a }}$ \\
\hline No. of patients: & 17 & 11 & 8 & 6 & 6 \\
M : F & $4: 13$ & $4: 7$ & $5: 3$ & $6: 0$ & $3: 3$ \\
Mean age (yr) & 59 & 73 & 48 & 61 & 51 \\
Age (range) & $(31-79)$ & $(60-82)$ & $(23-76)$ & $(31-79)$ & $(37-79)$ \\
\hline
\end{tabular}

a Of the other patients with PUK, 2 had no detectable systemic disease and the other 4 had different conditions (Crohn's disease, pyoderma gangrenosum, psoriasis, mesangio proliferative glomerulonephritis). 


\section{Detection of Antibodies to the $54 \mathrm{kDa}$ Corneal Antigen by ELISA}

Microtitration plates were incubated at $4{ }^{\circ} \mathrm{C}$ overnight with $200 \mu \mathrm{l}$ of either purified $54 \mathrm{kDa}$ corneal antigen $(10 \mu \mathrm{g} / \mathrm{ml})$ in PBS (pH 7.5) or $0.1 \%$ bovine serum albumin (BSA), in PBS/Tween ( $\mathrm{pH} 7.5$ ) per well. After washing with $\mathrm{PBS} / \mathrm{Tween}$, the remaining binding sites were blocked by loading the plates with $300 \mu \mathrm{l}$ of BSA/PBS/ Tween and incubated at room temperature for 1 hour. After washing with PBS/Tween, $200 \mu l$ of patients' or control sera diluted $1: 100$ in BSA/PBA/Tween $(\mathrm{pH} 7.5)$ was added to duplicate wells and incubated overnight at $4{ }^{\circ} \mathrm{C}$. After washing, $200 \mu \mathrm{l}$ of alkaline phosphatase-conjugated rabbit anti-human IgG, IgA or IgM (DAKO Ltd), diluted $1: 2000$ in BSA/PBS/Tween (pH 7.5) was added and incubated at room temperature for 1 hour. After further washing with PBS/Tween and finally with distilled water, the substrate, $p$-nitrophenyl phosphate (Sigma Ltd) was added at a concentration of $1 \mathrm{mg} / \mathrm{ml}$ in diethanolamine buffer, $\mathrm{pH}$ 9.8. The reaction was stopped by adding $50 \mu \mathrm{l}$ of $3 \mathrm{~mol} / \mathrm{l} \mathrm{NaOH}$. The developed colour was read at $405 \mathrm{~nm}$ on a Titretek MC plate reader. The mean of the duplicate absorbance values for the BSA blanks was subtracted from the mean of duplicate absorbance values of each sample on the same plate and the results were expressed as arbitrary absorbance units. The upper limit of normal was taken to be the mean value of the 49 normal blood donors plus 3 standard deviations. Sera giving absorbance values above the upper limit of normal were considered to be positive.

\section{RESULTS \\ Detection of Antibodies to Corneal Antigens by Immunofluorescence}

Antibodies to the corneal epithelium were demonstrated by indirect immunofluorescence in the majority of patients with PUK (91.3\%, 21/23), (Fig. 1a). Of these patients, all those who also had RA (11/11) or WG (6/6) and 66\% (4/6) of the remaining patients with PUK had antibodies directed against the corneal epithelium. The incidence of these antibodies in the systemic disease control groups without PUK was $23 \%$ (4/17) for patients with RA, 50\% (4/8) for patients with WG and 10\% (3/30) in the blood bank sera control group.

The staining of the corneal epithelium could be divided into two quite distinct patterns (Fig. 2): a diffuse stain covering the entire surface of the epithelium and a second 'lattice'-like pattern appearing to stain intercellular or membrane antigens. The lattice pattern was not restricted to the corneal epithelium but could be seen along the entire ocular surface including the corneal, limbal and conjunctival epithelia. The sera of some patients produced both types of staining pattern. Thirty-nine per cent $(9 / 23)$ of patients with PUK were positive for both patterns and only $4 \%$ (1/25) of patients without PUK were positive for both patterns. Neither pattern was specifically related to any particular disease group (Fig. 1b). Both staining patterns were reproducible on human and rat corneal epithelium.
No antibodies could be detected in patients' sera against epithelium from bovine skin, oesophagus or intestine using the above technique.

The predominant class of antibody staining the corneal epithelium was IgG, with IgA antibodies being present in only 3 patients, all of whom had WG and PUK.

\section{Detection of Antibodies to the Cornea by Immunoblotting}

Using the soluble corneal epithelial extract separated by SDS-PAGE as a substrate, a number of putative antigens were identified using patients' sera (Fig. 3). The number of protein bands to which serum antibodies bound varied considerably both within and between the different patient groups. The sera from 39\% (9/23) of patients with PUK bound to three or more bands and of these 9 patients, 5 had both immunofluorescent staining patterns. Only 9\% (2/ 21) of serum samples from patients without PUK, tested in the immunoblotting assay, bound to three or more bands (Table II).

No band was found to be specific for a single diagnosis. Fifty-seven per cent (8/14) of serum samples from patients with WG were positive for band 11 irrespective of the presence or absence of ocular inflammation and the degree
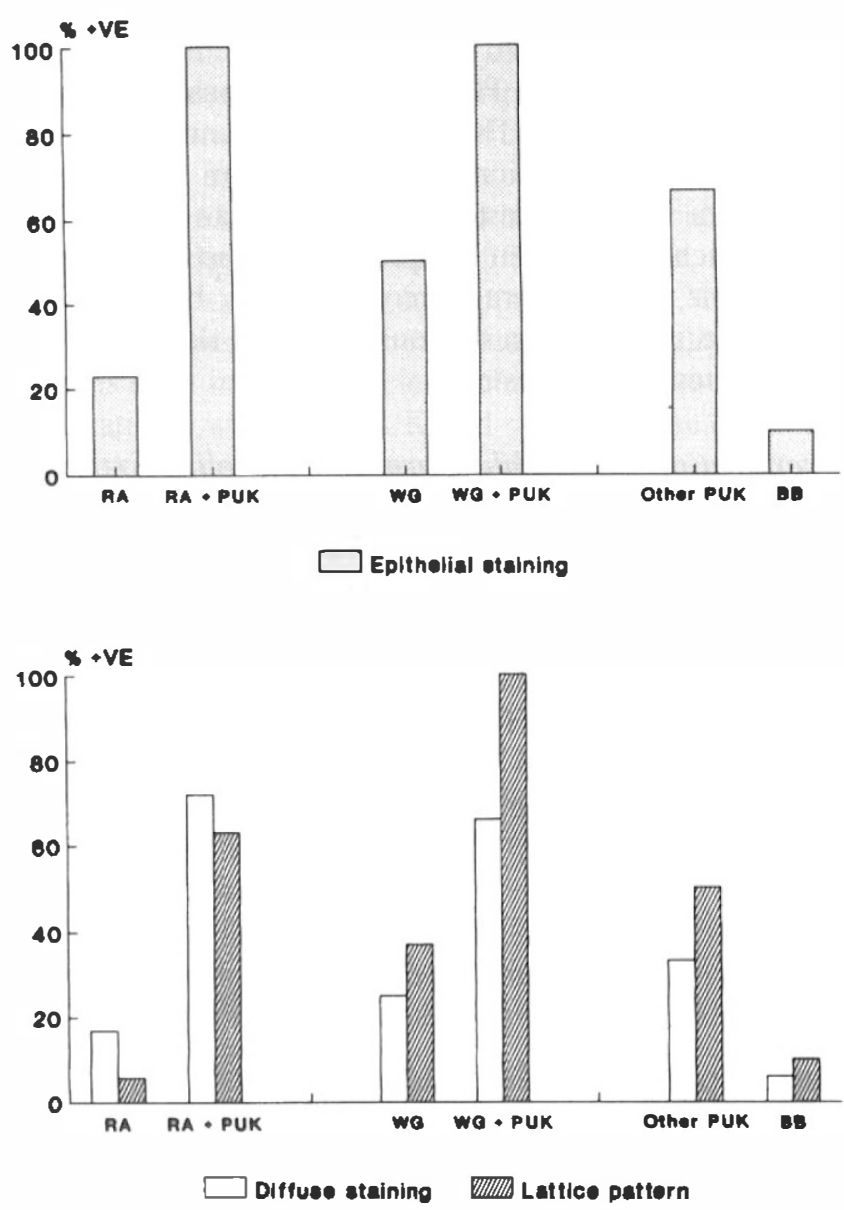

Fig. 1. Antibodies to corneal epithelium in patients' sera, detected by immunofluorescence. (a) Percentage of patients with epithelial staining. (b) Staining subdivided into diffuse or lattice pattern. BB, blood bank controls. 


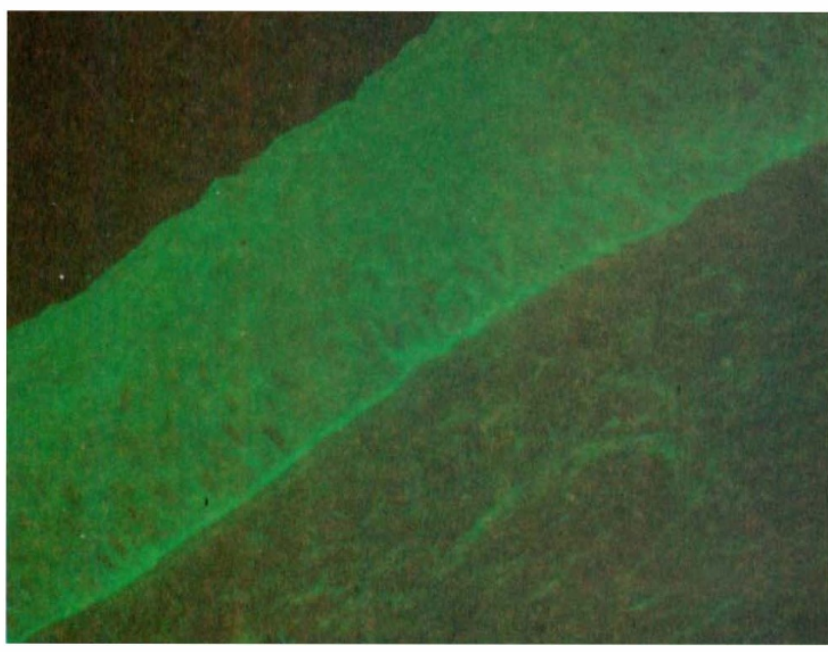

(a)

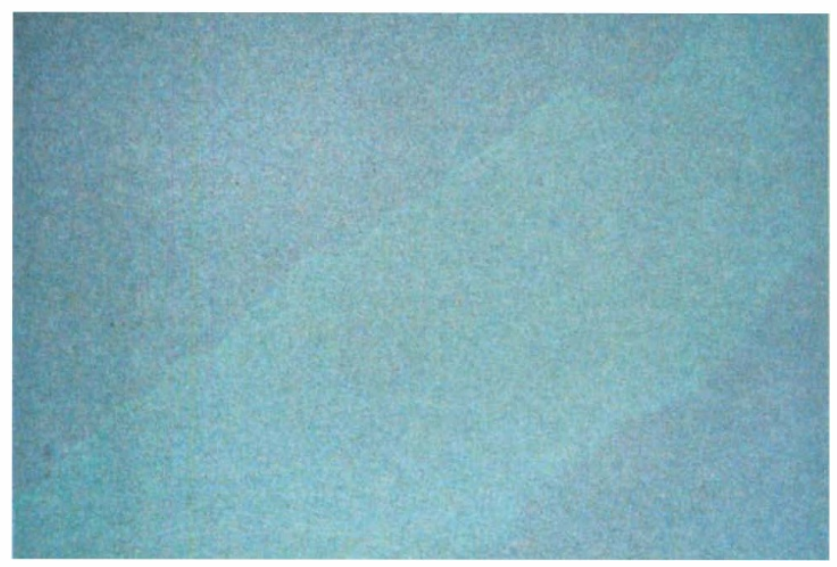

(c)

of activity of disease (Table III). Band 11 appeared to be present only in the corneal extract and it had an approximate molecular weight of $70 \mathrm{kDa}$. Antibodies to band 9, $54 \mathrm{kDa}$ protein or BCP54, a protein specific to the cornea,

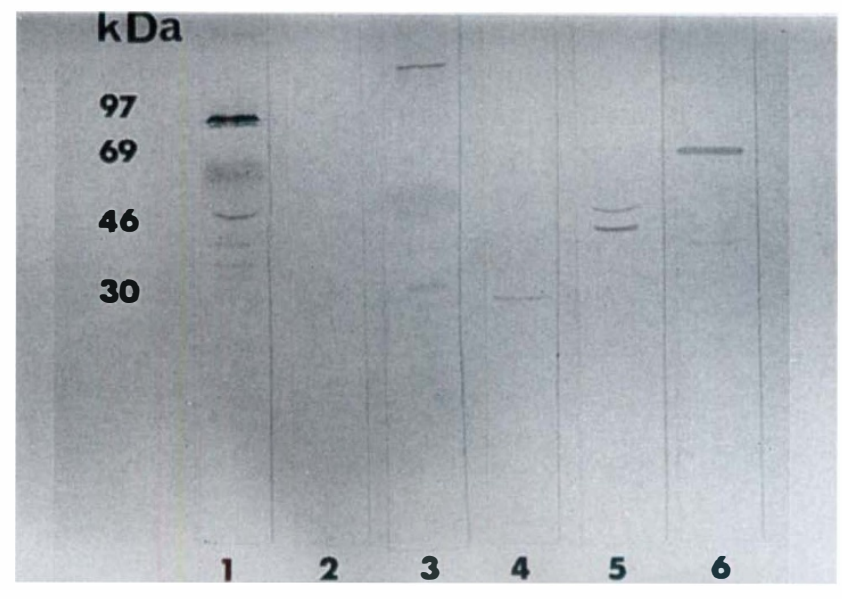

Fig. 3. Immunoblotting of patient's serum on corneal epithelial proteins. Lane 1, patient's serum binding to many bands in the extract. Lane 2, patient's serum binding to no bands. Lanes 3-6, serum from patients with PUK binding to a range of protein bands: lane 3, bands 5, 9 and 13; lane 4, band 4; lane 5, bands 7 and 8; lane 6, band 11 .

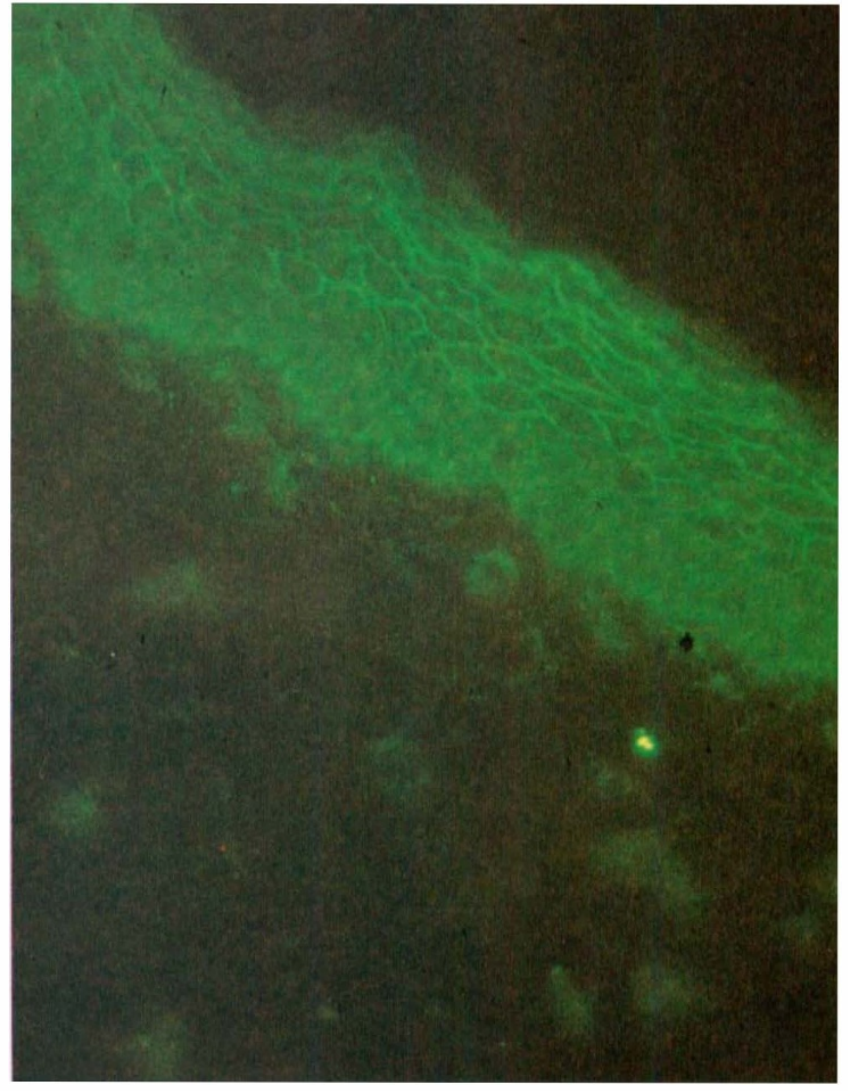

(b)

Fig. 2. Immunoflurescent staining on corneal sections. (a) Patient's serum demonstrating diffuse staining pattern in corneal epithelium. (b) Patient's serum demonstrating lattice pattern in the conjunctival epithelium. (c) Patient's serum showing a negative result.

occurred in $39 \%(9 / 23)$ of patients with corneal melt, and only $9 \%(2 / 21)$ of patients without ocular complications tested in the assay. Of serum samples.from patients with RA $37.5 \%$ (9/24) were positive for bands 7 and 8 (Table III). Proteins of a similar molecular weight to bands 7 and 8 (approximately 50 and $53 \mathrm{kDa}$ ) were also detected by antibodies from patients' sera in other tissue extracts, demonstrating that they are not specific to the cornea.

\section{Detection of Antibodies to the $54 \mathrm{kDa}$ Protein by ELISA}

The patients' sera were tested using ELISA for IgG, IgM or IgA antibodies to the $54 \mathrm{kDa}$ protein. Thirty-five per cent $(8 / 23)$ of patients with PUK had IgG antibody levels above the upper limit of normal to the $54 \mathrm{kDa}$ protein, compared with only $8 \%(2 / 22)$ of patients with systemic disease but without ocular complications tested by ELISA (Fig. 4). Antibodies to the $54 \mathrm{kDa}$ protein occurred in the serum of some patients with PUK in isolation or in association with RA or WG, demonstrating that these antibodies were not restricted to any particular disease. No patients had IgM or IgA antibodies to the $54 \mathrm{kDa}$ protein.

Comparison of immunofluorescence staining patterns with the ELISA and immunoblotting results in individual 
Table II. The number of protein bands in the corneal epithelial extract to which antibodies were detected by immunoblotting in different patient groups

\begin{tabular}{lcccccc}
\hline $\begin{array}{l}\text { No.of bands to } \\
\text { which sera bind }\end{array}$ & $\begin{array}{l}\text { WG } \\
(8)^{a}\end{array}$ & $\begin{array}{c}\text { WG + PUK } \\
(6)\end{array}$ & $\begin{array}{c}\text { RA } \\
(13)\end{array}$ & $\begin{array}{c}\text { RA + PUK } \\
(11)\end{array}$ & $\begin{array}{c}\text { Other } \\
\text { PUK (5) }\end{array}$ & $\begin{array}{c}\text { Normals } \\
(11)\end{array}$ \\
\hline 0 & 1 & 3 & 8 & 4 & 0 & 9 \\
1 & 4 & 0 & 2 & 1 & 2 & 2 \\
2 & 2 & 0 & 2 & 2 & 1 & 0 \\
3 & 1 & 0 & 0 & 2 & 1 & 0 \\
4 & 0 & 3 & 1 & 2 & 1 & 0 \\
\hline
\end{tabular}

${ }^{a}$ Number of patients.

patients suggests that the diffuse staining seen in immunofluorescence is related to the presence of antibodies to the $54 \mathrm{kDa}$ protein in some patients. The presence of the lattice pattern by immunofluorescence did not correlate either with the presence of antibodies to the $54 \mathrm{kDa}$ protein or with antibodies to any other protein from the corneal extract identified in the immunoblotting assay.

\section{Detection of Antibodies to Corneal Antigens During the Course of Disease Using Serial Samples}

Thirty-one sequential serum samples were available from one patient, CR, with severe WG and PUK, who required aggressive immunosuppressive therapy. These sera were tested by immunofluorescence, immunoblotting and ELISA to the $54 \mathrm{kDa}$ protein. The first sample taken during the first episode of PUK was positive for the lattice pattern but negative in the ELISA for antibodies to the $54 \mathrm{kDa}$ protein (Fig. 5). The lattice pattern became undetectable upon resolution of the PUK. However, antibodies to the $54 \mathrm{kDa}$ protein as measured by ELISA did not become elevated until 7 months after the onset of melt, at which time the condition was quiescent.

Serial samples from 16 other patients were also investigated for fluctuations in antibody levels during the course of the disease. Nine were WG patients and 4 of these also had an episode of PUK; the other 7 were RA patients of whom 4 also had an episode of PUK. In 3 patients with WG and PUK, serum samples taken later in the course of disease or after resolution of the PUK were negative for the 'lattice' pattern, whereas earlier samples had been positive. Band 9, the $54 \mathrm{kDa}$ protein, was the only protein to which patients' antibody levels fluctuated in the immu- noblotting assay; the same results were also seen when antibodies to the $54 \mathrm{kDa}$ protein were measured by ELISA. In 4 patients, including patient $\mathrm{CR}$, antibodies to the $54 \mathrm{kDa}$ protein were undetectable at the outset of the PUK but in all cases became detectable later. In one patient with WG but no apparent ocular symptoms, antibodies to the $54 \mathrm{kDa}$ protein fluctuated over a period of 3 years.

\section{DISCUSSION}

Antibodies directed against the corneal epithelium were found in $91.3 \%$ of patients with PUK compared with $36 \%$ of patients without PUK and only $10 \%$ of control sera, suggesting that corneal antibodies detected by immunofluorescence were related to the ocular rather than the systemic condition. The two distinct immunofluorescent patterns seen suggest at least two antigens were targeted by antibodies, whilst immunoblotting to a corneal epithelial extract showed that antibodies to a larger number of antigens occurred.

Corneal antibodies are not, however, restricted to patients with PUK. Circulating antibodies to the cornea have been detected in sera from patients with uveitis, Fuchs' heterochromic cyclitis and also in other systemic disease such as Behçet's disease in which the cornea is not typically involved (La Hey, ${ }^{19} \mathrm{Kong}^{20}$ and personal observations). Also in this study $36 \%$ of patients with systemic disease without any ocular complications had circulating antibodies to the cornea, suggesting that the presence of antibodies alone is insufficient to cause corneal disease. It may be that accessibility of the antigens to the immune system is important, as it has been shown in the rat that although antibody production may be easily triggered, the antibodies do not reach a healthy cornea. ${ }^{21}$

Table III. Number of patients in each group with antibodies to individual protein bands in the corneal epithelial extract

\begin{tabular}{|c|c|c|c|c|c|c|}
\hline Band no. & $\begin{array}{l}\text { WG } \\
(8)^{a}\end{array}$ & $\begin{array}{c}\mathrm{WG}+\mathrm{PUK} \\
\text { (6) }\end{array}$ & $\begin{array}{l}\text { RA } \\
\text { (13) }\end{array}$ & $\begin{array}{c}\mathrm{RA}+\mathrm{PUK} \\
(11)\end{array}$ & $\begin{array}{c}\text { Other } \\
\text { PUK (5) }\end{array}$ & $\begin{array}{c}\text { Normals } \\
\text { (11) }\end{array}$ \\
\hline 1 & 0 & 0 & 0 & 0 & 0 & 0 \\
\hline 2 & 0 & 1 & 0 & 0 & 1 & 0 \\
\hline 3 & 0 & 0 & 0 & 0 & 0 & 0 \\
\hline 4 & 0 & 1 & 0 & 0 & 1 & 0 \\
\hline 5 & 0 & 1 & 1 & 0 & 2 & 0 \\
\hline 6 & 0 & 1 & 0 & 1 & 1 & 0 \\
\hline 8 & 1 & 2 & 3 & 6 & 1 & 0 \\
\hline 9 & 1 & 2 & 1 & 4 & 3 & 1 \\
\hline 10 & 1 & 2 & 1 & 1 & 0 & 0 \\
\hline 11 & 5 & 3 & 1 & 2 & 1 & 1 \\
\hline 12 & 1 & 0 & 2 & 0 & 0 & 0 \\
\hline
\end{tabular}

The four most frequently detected bands are emboldened. Antibodies to bands 7 and 8 occurred in $9 / 24 \mathrm{RA}$ patients, to Band 9 in $9 / 22$ PUK patients, and to Band 11 in $8 / 14 \mathrm{WG}$ patients. ${ }^{\mathrm{a}}$ Number of patients. 


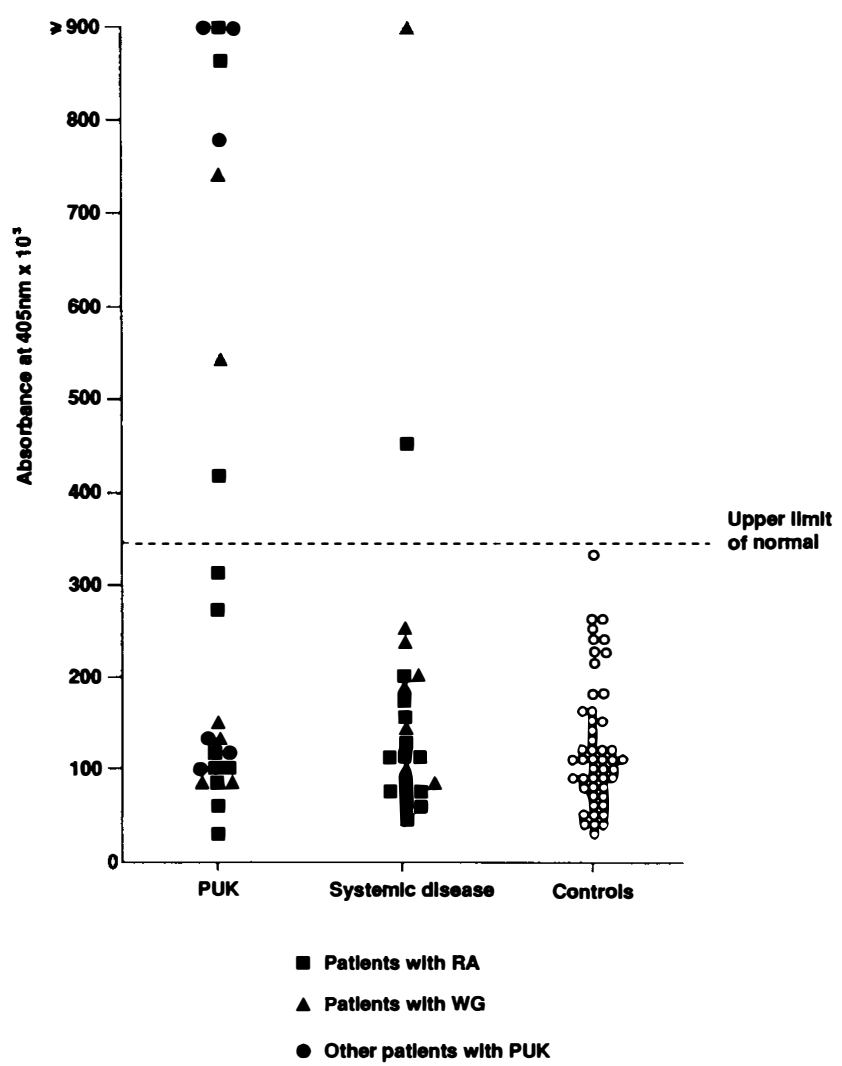

Fig. 4. Antibodies to the $54 \mathrm{kDa}$ protein in serum from patients and controls as measured by ELISA.

Patients with systemic disease may have antibodies which bind to tissue components which cross-react with antigens in the cornea. Indeed some of these antigens are not corneal specific as antibodies bound to similar antigens in other tissue extracts in the immunoblotting assay. Fluorescence staining, however, was only seen in corneal sections. This may be due to the different sensitivities of the immunoblotting and fluorescence assays or the fact that different antigens were detected by the two techniques.

One corneal-specific antigen, the soluble $54 \mathrm{kDa}$ protein, has previously been described as an autoantigen in corneal disease. ${ }^{8}$ The $54 \mathrm{kDa}$ protein is the most abundant soluble protein in the cornea, constituting $30 \%$ of the soluble proteins. ${ }^{15}$ From amino acid sequencing and cDNA studies the protein shows a high sequence homology with a rat tumour-associated aldehyde dehydrogenase (RATALD) ${ }^{22,23}$ The protein has also been identified biochemically as an aldehyde dehydrogenase in bovine and human cornea and both structural and enzymic roles have been suggested. ${ }^{23-25}$ Abedina et al. proposed a protective role for the cornea, via oxidation of aldehydes generated by light-induced lipid peroxidation, and the direct absorption of UV-B light by the enzyme. ${ }^{24}$ In our study antibodies from $35 \%$ of patients with PUK bound to the $54 \mathrm{kDa}$ protein by both immunoblotting and ELISA compared with $8 \%$ of patients with systemic disease only. A similar incidence of immunity to the $54 \mathrm{kDa}$ protein in patients with corneal melt was described by Kruit $e t$ al. who also described both humoral and cellular responses to this antigen. ${ }^{8}$

Autoimmunity to the $54 \mathrm{kDa}$ protein has also been described in other conditions: $71 \%$ of Fuch's heterochromic cyclitis patients had a positive cellular response to the $54 \mathrm{kDa}$ protein, but with only one third of patients having both cellular and humoral immunity. ${ }^{26}$ Immunity to the $54 \mathrm{kDa}$ protein has also been described in corneal transplantation recipients, where the authors concluded that an anti-corneal response may be a result of an intraocular inflammatory response in those patients. ${ }^{13}$

The antibody status of a patient based on a single time point sample, however, may not reflect the true situation over a period of time. In 5 of our patients with elevated levels to the $54 \mathrm{kDa}$ antigen, serial samples were available and antibody levels fluctuated in all 5. Four of these patients had at least one episode of PUK in combination with either WG or RA. In all these patients antibodies to the $54 \mathrm{kDa}$ antigen only became detectable after the episode of PUK, when the eye had become quiescent. This information supports the hypothesis that antibodies to the $54 \mathrm{kDa}$ protein are produced as a response to tissue damage in the cornea brought about by the disease process, and that they do not play any role in the initiation of the condition.

Nevertheless if an autoimmune response to the $54 \mathrm{kDa}$ protein plays no role in the initiation of the ocular condition, an immune response initiated as a result of ocular inflammation to an enzyme with an important protective role may have a pathogenic role in the disease process.

Antibodies to corneal antigens were detected which appeared to be associated more with a systemic disease rather than the ocular condition. In the systemic disease groups, $37.5 \%$ of patients with RA were positive to bands 7 and 8 in the immunoblotting assay and $57 \%$ of patients with WG were positive to band 11, irrespective of whether or not ocular manifestations were present. Bands 7 and 8 appeared to occur in other tissues and therefore antibodies may be cross-reacting with antigens in both ocular and other tissues. Band $11(70 \mathrm{kDa})$ was not detected by antibodies in any of the other tissues tested, suggesting it may be corneal-specific, but the nature of this antigen is at present unknown.

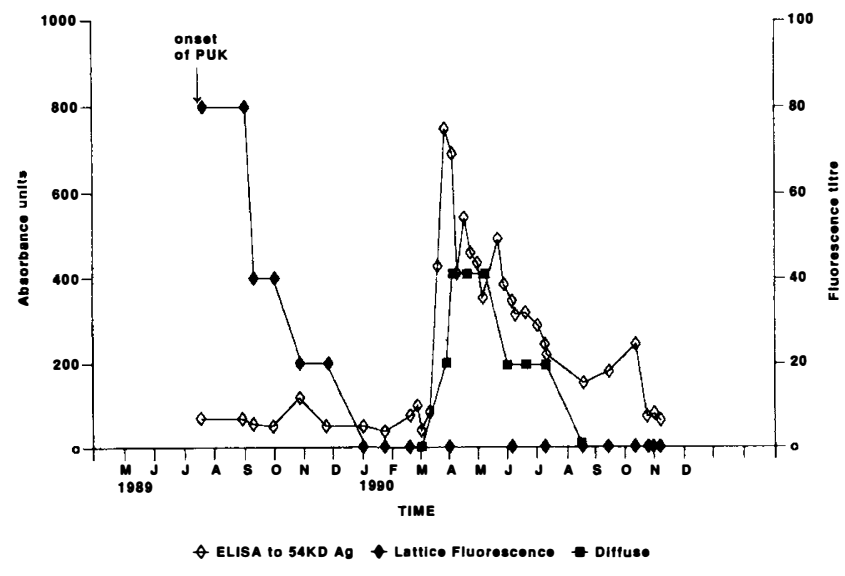

Fig. 5. Antibody titres in serial samples from one patient, $C R$, as measured by ELISA and immunofluorescence. 
The detection of a lattice pattern by immunofluorescence was related to patients with PUK and particularly with WG $(100 \%)$. The lattice pattern was present at the onset of disease in all the patients with WG and PUK and in 50\% of cases the staining was lost upon remission of the PUK. The antibodies responsible for the lattice pattern may, therefore, be important in the initiation of the pathological processes. There was no correlation between any antigen identified by the immunoblotting assay and the presence of the lattice pattern. The nature of these antigens is at present unknown, but from the location of the fluorescent staining the antigen may be an insoluble membrane protein which would not have been isolated in the extraction procedure used so far in our investigation.

The onset of PUK tends to occur at different stages of the two diseases. In the patients with WG, the ocular condition was often a presenting problem which was important in the diagnosis of the systemic disease. The patients with RA all had the diagnosis of RA for between 10 and 15 years before the onset of PUK. It is of interest, therefore, that differences are seen between the two systemic disease groups.

From this work it has become clear that antibodies in these patients are directed against a large number of corneal antigens and some of these antibodies may be important in the pathogenesis of ocular disease. We have shown that antibodies to some corneal antigens are related to the systemic rather than ocular condition. In our patients, antibodies to the $54 \mathrm{kDa}$ protein occur after ocular tissue damage and probably play no role in the initiation of PUK. The presence of the immunofluorescent 'lattice' pattern, however, is more strongly related to the onset of PUK in patients with WG, and these antibodies may be a prognostic marker for corneal disease and may be involved in the pathogenesis. In order to elucidate the role of these antibodies further it will be necessary to learn more of the nature of the antigens involved.

The authors wish to acknowledge the assistance of Doreen Ward in the preparation of the manuscript. This study is supported by a grant from the North West Regional Health Authority.

Key words: Autoantibodies, Bovine corneal specific protein, Cornea, Peripheral ulcerative keratitis, Rheumatoid arthritis, Wegener's granulomatosis.

\section{REFERENCES}

1. Brown SI and Grayson M: Marginal furrows: a characteristic corneal lesion of rheumatoid arthritis. Arch Ophthalmol 1968, 79: 563-7.

2. Mondino BJ: Inflammatory diseases of the peripheral cornea. Ophthalmology 1988, 95: 463-72.

3. Michels ML, Cobo M, Caldwell DS, Rice JR, Haynes BF: Rheumatoid arthritis and sterile corneal ulceration. Arthritis Rheum 1984, 27: 606-14.

4. Ferry AP and Leopold IH: Marginal (ring) corneal ulcer as presenting manifestations of Wegener's granulomatosis. Ophthalmologica 1970, 74: 1276.

5. Mondino BJ, Brown SI, Rabin BS: Autoimmune phenomena of the external eye. Ophthalmology 1978, 85: 801-17.

6. Schaap OL, Feltkamp TEW, Breebaart AC: Circulating antibodies to corneal tissue in patients suffering from Moor- en's ulcer (ulcus rodens cornea). Clin Exp Immunol 1969, 5: 365-70.

7. Gaag van der R, Abdillahi H, Stilma JS, Vetter JCM: Circulating antibodies against corneal epithelium and hookworm in patients with Mooren's ulcer from Sierra Leone. $\mathrm{Br} J$ Ophthalmol 1983, 67: 623-8.

8. Kruit PJ, Gaag van der R, Broersma L, Kijlstra A: Autoimmunity against corneal antigens. I. Isolation of a soluble 54 kD corneal epithelial antigen. Curr Eye Res 1986, 5: 313-20.

9. Berkowitz PJ, Arentsen JJ, Felberg NT, Laibson PR: Presence of circulating immune complexes in patients with peripheral corneal disease. Arch Ophthalmol 1983, 101: 242-5.

10. Mondino BJ, Brown SI, Rabin BS: Cellular immunity in Mooren's ulcer. Am J Ophthalmol 1978, 85: 788-91.

11. Murry PI, Rahi AHS: Pathogenesis of Mooren's ulcer: some new concepts. Br J Ophthalmol 1984, 68: 182-7.

12. Stark WJ: Transplantation immunology of penetrating keratoplasty. Trans Am Ophthalmol Soc 1980, 88: 1079-17.

13. Jager M, Volker-Dieben HJ, Vos A, Broesma L, Kok F, Van der Gaag R: Cellular and humoral immune response in corneal transplantation. Arch Ophthalmol 1991, 109: 972-7.

14. Kruit PJ: 1988 Corneal Autoimmunity: A Clinical and Experimental Approach. [Thesis] Amsterdam: Free University Press.

15. Alexander RJ, Silverman B, Henley WL: Isolation and characterisation of BCP54, the major soluble protein of the bovine cornea. Exp Eye Res 1981, 32: 205-16.

16. Silverman B, Alexander RJ, Henley WL: Tissue and species specificity of BCP54, the major soluble protein of the bovine cornea. Exp Eye Res 1981, 33: 19-29.

17. Arnett FC, et al.: The American Rheumatism Association 1987 revised criteria for the classification of rheumatoid arthritis. Arthritis Rheum 1987, 31: 315-24.

18. Leavitt RL, et al.: The American College of Rheumatology 1990 criteria for the classification of Wegener's granulomatosis. Arthritis Rheum 1990, 33: 1101-7.

19. La Hey E, Baarsma GS, Rothova A, Broersma L, Van der Gaag R, Kijlstra A: High incidence of corneal epithelium antibodies in Fuchs' heterochromic cyclitis. Br J Ophthalmol 1988, 72: 921-5.

20. Kong AS, Henley WL, Luntz MH: Longitudinal study of serum antibody response to bovine corneal protein (BCP54) in Behçet's disease. Ophthalmol Res 1989, 21: 401-5.

21. Eijpe AA, Kruit PJ, Van der Gaag VR, Neuteboom GH, Broesma L, Kijlstra A: Autoimmunity against corneal antigens. II. Accessibility of $54 \mathrm{kD}$ corneal antigen for circulating antibodies. Curr Eye Res 1987, 3: 467.

22. Cooper DL, Baptist EW, Enghild J, Lee H, Isola N, Klintworth GK: Partial amino acid sequence determination of bovine corneal protein 54 kD (BCP54). Curr Eye Res 1990, 9: 781-6.

23. Cooper D, Baptist E, Enghild JL, Narayana RI, Klintworth $\mathrm{GK}$ : Bovine corneal protein $54 \mathrm{kD}$ (BCP54) is a homologue of the tumor-associated class 3 rat aldehyde dehydrogenase (RATALD). Gene 1991, 98: 201-7.

24. Abedina M, Pain T, Algar EM, Holmes RS: Bovine corneal aldehyde dehydrogenase: the major soluble corneal protein with a possible dual protective role for the eye. Exp Eye Res 1990, 51: 419-26.

25. Gondhowiardjo TD, van Haeringen NJ, Hoekzema R, Pels L, Kijlstra A: Detection of aldehyde dehydrogenase activity in human corneal extracts. Curr Eye Res 1991, 10: 1001-7.

26. Van der Gaag R, Broersma L, Rothova A, Baarsma S, Kijlstra A: Immunity to a corneal antigen in Fuchs' heterochromic cyclitis patients. Invest Ophthalmol Vis Sci 1989, 30: 443-7. 